\title{
Conjugates of methylated cyclodextrin derivatives and hydroxyethyl starch (HES): Synthesis, cytotoxicity and inclusion of anaesthetic actives
}

\author{
Lisa Markenstein ${ }^{1}$, Antje Appelt-Menzel ${ }^{2}$, Marco Metzger $^{2}$ and Gerhard Wenz ${ }^{* 1}$
}

\author{
Full Research Paper \\ Address: \\ ${ }^{1}$ Organic Macromolecular Chemistry, Saarland University, Campus \\ C4.2, 66123 Saarbrücken, Germany and ${ }^{2}$ Department of Tissue \\ Engineering and Regenerative Medicine, University Hospital \\ Würzburg, Röntgenring 11, 97070 Würzburg, Germany \\ Email: \\ Gerhard Wenz* - g.wenz@mx.uni-saarland.de \\ * Corresponding author \\ Keywords: \\ anaesthetics; complexation; cyclodextrin; LCST; lower critical solution \\ temperature; midazolam; occupancy; polymer; sevoflurane; solubility; \\ starch
}

\author{
Beilstein J. Org. Chem. 2014, 10, 3087-3096. \\ doi:10.3762/bjoc. 10.325 \\ Received: 22 August 2014 \\ Accepted: 08 December 2014 \\ Published: 19 December 2014 \\ This article is part of the Thematic Series "Superstructures with \\ cyclodextrins: Chemistry and applications II". \\ Associate Editor: H. Ritter \\ (C) 2014 Markenstein et al; licensee Beilstein-Institut. \\ License and terms: see end of document.
}

\begin{abstract}
The mono-6-deoxy-6-azides of 2,6-di- $O$-methyl- $\beta$-cyclodextrin (DIMEB) and randomly methylated- $\beta$-cyclodextrin (RAMEB) were conjugated to propargylated hydroxyethyl starch (HES) by $\mathrm{Cu}^{+}$-catalysed [2+3] cycloaddition. The resulting water soluble polymers showed lower critical solution temperatures (LCST) at $52.5^{\circ} \mathrm{C}$ (DIMEB-HES) and $84.5{ }^{\circ} \mathrm{C}$ (RAMEB-HES), respectively. LCST phase separations could be completely avoided by the introduction of a small amount of carboxylate groups at the HES backbone. The methylated CDs conjugated to the HES backbone exhibited significantly lower cytotoxicities than the corresponding monomeric CD derivatives. Since the binding potentials of these CD conjugates were very high, they are promising candidates for new oral dosage forms of anaesthetic actives.
\end{abstract}

\section{Introduction}

Cyclodextrins (CDs), $\alpha(1 \rightarrow 4)$ linked cyclic oligomers of anhydroglucose, are produced nowadays in industrial scale [1]. CDs are able to complex hydrophobic or amphiphilic guest molecules in aqueous phase [2]. $\beta-\mathrm{CD}$, the seven membered ring forms inclusion compounds with derivatives of benzene, naphthalene, adamantane, and many other moieties of similar sizes [3]. Applications of $\beta-\mathrm{CD}$ as complexing agents are limited because of low aqueous solubilities of $\beta-C D$ and its complexes. Furthermore, the toxic potential of $\beta-C D$ is known for a long time. $\beta-C D$ can cause haemolysis due to extraction of cholesterol from cell walls $[4,5]$. Also the parenteral application of high doses of $\beta-C D$ can cause kidney diseases [6,7]. Consequently, pharmaceutical applications of $\beta-C D$ are restricted to oral dosage forms, such as piroxicam $\beta-\mathrm{CD}$ [8-10]. 
Toxicity of $\beta-C D$ can be minimized by derivatisation $[11,12]$. Both, hydroxypropyl- $\beta-\mathrm{CD}$ (HP- $\beta-\mathrm{CD})$ and sulfobutyl- $\beta-\mathrm{CD}$ are less toxic than $\beta-C D$, but they are less defined due to a statistical substitution pattern [13]. HP- $\beta$-CD often shows a reduced binding potential compared to $\beta-\mathrm{CD}[2,14]$. On the other hand, methylation of $\beta-\mathrm{CD}$ leads to excellent solubilities in water and high binding potentials, but causes even higher toxicity compared to native $\beta$-CD. Among the methyl derivatives of $\beta$-CD the heptakis-2,6-di- $O$-methyl derivative, abbreviated as DIMEB [15], showed very high binding potentials [16] and was already discussed by Szejli as a very promising candidate for parenteral drug delivery [17], but it was placed back because of its high toxicity $[5,18,19]$. Therefore our aim was to conjugate DIMEB for the first time to a polymeric backbone, which should hinder cellular uptake. CD polymers are known to have a much lower toxic potential compared to CD monomers [20].

Native $\beta$-CD was already conjugated by esterification [21], reductive amination [22-25], amide coupling [26,27] and [2+3] cycloadditions [28] to both biogenic and synthetic polymers. Conjugation of CDs to polysaccharides like chitosane [29], alginate [24] and dextrane [28] is advantageous for the design of drug delivery systems because of the low toxicities and biodegradabilities of those polymers. Among the various coupling reactions, the $[2+3]$ cycloaddition of alkynes and azides, the so-called Huisgen reaction [30] and its $\mathrm{Cu}^{+}$catalyzed version, called click reaction $[31,32]$, is of special interest because this coupling proceeds rapidly and specific in aqueous media and tolerates many functional groups. Mono-6azido-6-deoxy- $\beta$-CD was already coupled by the click reaction to propargylated dextrane by Nielsen et al. [28]. We intended to conjugate the corresponding methylated mono-azido- $\beta$-CD derivatives to propargylated hydroxyethyl starch (HES). Advantages of HES are its very high aqueous solubility paired with good biocompatibility and its very low allergenic potential [33]. HES is in use for a long time for many parenteral applications, such as plasma expanders [34]. Its rate of bio-degradation increases with decreasing the degree of substitution (MS) of the hydroxyethyl side groups. Nowadays, HES with a molecular weight of $M_{\mathrm{w}}=130 \mathrm{kDa}$ and $\mathrm{MS}<0.5$ is preferred [35]. In the following, we describe the conjugation of azido-functionalized methylated $\beta-C D$ derivatives to propargylated HES, the evaluation of the toxicity of these new polymers and first binding studies for the hydrophobic anaesthetic ingredients sevoflurane and midazolam. Sevoflurane, currently applied as an inhalation anaesthetic [36], could be solubilized in water to allow further use in oral or parenteral dosage forms as an analgesic drug. Also the uptake of midazolam could be improved by complexation in CD derivatives [37,38].

\section{Results and Discussion}

Cyclodextrin polymers were synthesized by copper-catalyzed $[2+3]$ cycloaddition of methylated derivatives of mono- 6 azido-6-deoxy- $\beta$-CD $\left(\beta-\mathrm{CD}-\mathrm{N}_{3}\right)$ and propargylated hydroxyethyl starch (HES). Furthermore, a partially oxidized propargylated HES was employed as hydrophilic polymer backbone.

The methylated $\beta-\mathrm{CD}-\mathrm{N}_{3}$ was synthesized in a 3 step procedure starting from $\beta-\mathrm{CD}$ which was first converted via the 6-O-tosylate to $\beta-\mathrm{CD}-\mathrm{N}_{3}$ following the procedures of Hocquelet et al. who also described the permethylated $\beta-\mathrm{CD}-\mathrm{N}_{3}$ [39]. Furthermore, we headed for the regioselective 2,6-dimethylated product. Therefore $\beta-\mathrm{CD}-\mathrm{N}_{3}$ was carefully methylated by dimethyl sulfate and a mixture of $\mathrm{Ba}(\mathrm{OH})_{2} \cdot 8 \mathrm{H}_{2} \mathrm{O}$ and $\mathrm{BaO}$ as the base following the procedure of Szejtli et al. published for the methylation of native $\beta$-CD [15] (Scheme 1).

The product 1a showed a quite narrow distribution of methyl substituents as revealed by the ESIMS showing signals corresponding to $\beta-\mathrm{CD}-\mathrm{N}_{3}$ derivatives with 14 to 18 methyl groups (Figure 1). From the average number of the molecular weight obtained from the ESIMS, $M_{\mathrm{n}}=1383.6 \mathrm{~g} \mathrm{~mol}^{-1}$ a degree of substitution of methyl groups $\mathrm{DS}_{\mathrm{CD}}$ (methyl) $=2.2$ per glucose unit was derived.

This value of $\mathrm{DS}_{\mathrm{CD}}$ (methyl) was confirmed by the well resolved ${ }^{1} \mathrm{H}$ NMR spectrum (Figure 2). After setting the integral of the H-3 proton to 1 the signals in the range between 4.8 and $5.4 \mathrm{ppm}$ integrated to a value of 12.18 protons. Taking into account the 7 anomeric protons $5.18 \mathrm{OH}$ protons per $\mathrm{CD}$ are

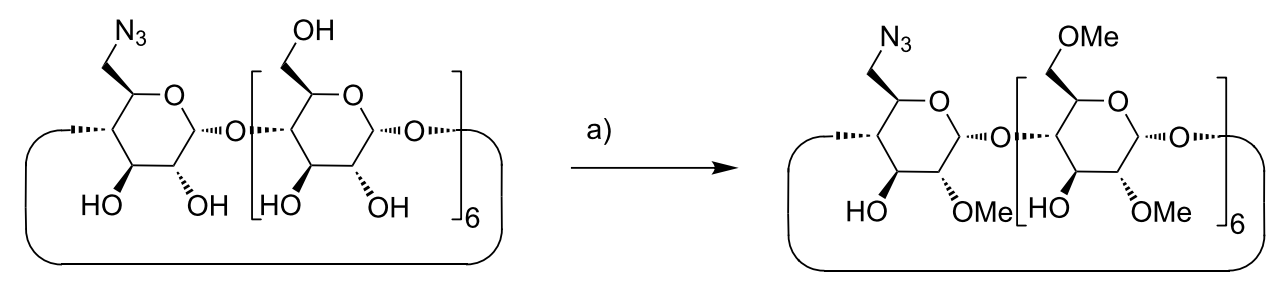




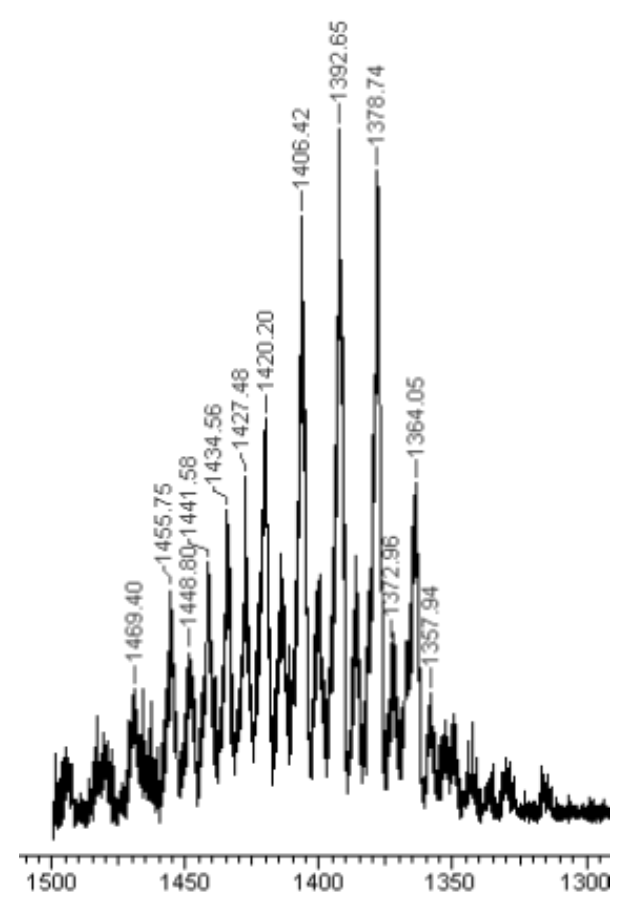

Figure 1: ESI mass spectrum of azido functionalized DIMEB 1a

left, which is equivalent to a $\mathrm{DS}_{\mathrm{CD}}$ (methyl) $=2.2$. The signals at $3.66 \mathrm{ppm}$ and $3.43 \mathrm{ppm}$ were assigned to the methyl groups in O-2 and O-6 position, respectively [40]. Nearly no signal was found corresponding to methyl groups in O-3 position. If the according methylation was instead performed with $\mathrm{NaOH}$ as the base it proceeded much faster and with a high chance of overmethylation. Careful control of the reaction time lead to another product $\mathbf{1 b}$ with a similar degree of methylation $\mathrm{DS}_{\mathrm{CD}}$ (methyl) $=2.3$, but a much higher structural heterogeneity as demonstrated by the ${ }^{1} \mathrm{H}$ NMR spectrum (Figure $3 \mathrm{~s}$, Supporting Information File 2) which was much less resolved than the spectrum of 1a (Figure 2a). Methylations employing
$\mathrm{NaOH}$ as the base [41] are known to be less regioselective than those using barium hydroxide [41].

A commercial HES with an average molar mass $M_{\mathrm{w}}=130 \mathrm{kDa}$ and a molar degree of substitution of MS(hydroxyethyl) $=0.4$ was functionalized by reaction with propargyl glycidyl ether in water (Scheme 2) in analogy to a procedure published by Nielsen et al. for the synthesis of $\beta$-CD-dextran polymers [28]. The degree of substitution of HES with propargyl groups, $\mathrm{DS}_{\mathrm{HES}}$ (propg), was determined by ${ }^{1} \mathrm{H}$ NMR spectroscopy from the integral of the methylene protons of the propargyl groups $\mathrm{H}-12$ at $4.75 \mathrm{ppm}$ relative to the ones of the anomeric proton $\mathrm{H}-01$ of starch at around $5.5 \mathrm{ppm}$ (Figure 2b). Surprisingly $\mathrm{DS}_{\mathrm{HES}}$ (propg) increased with decreasing concentration of the base $\mathrm{NaOH}$. Only a moderate $\mathrm{DS}_{\mathrm{HES}}$ (propg) $=0.4$ could be reached in $0.75 \mathrm{M} \mathrm{NaOH}$, while a higher $\mathrm{DS}_{\mathrm{HES}}$ (propg) $=0.65$ was accomplished in $0.1 \mathrm{M} \mathrm{NaOH}$ after $2 \mathrm{~d}$ reaction time. The decreasing yield was rationalized by the increasing consumption of propargyl glycidyl ether by hydrolysis with increasing $\mathrm{OH}^{-}$concentration. On the other hand, due to the low $\mathrm{p} K_{\mathrm{a}} \approx 12$ of polyglucanes, deprotonation still takes place at very low concentrations of $\mathrm{OH}^{-}[42,43]$. Indeed the modification of HES seems to take place exclusively at the unsubstituted glucose units, because the signal of the anomeric proton $\mathrm{H}-01$ of the unsubstituted glucose unit at $5.4 \mathrm{ppm}$ [44] of HES (see Figure 1s, Supporting Information File 2) had nearly completely vanished in the product spectrum shown in Figure 2b. The HES derivative with $\mathrm{DS}_{\mathrm{HES}}$ (propg) $=0.65,2$, was selected for the further coupling to azido-CD derivatives. Also a hydroxyethyl starch, where the $\mathrm{CH}_{2} \mathrm{OH}$ groups had been partially oxidized by TEMPO to carboxylate groups $[45,46]$, was functionalized by reaction with glycidyl propargyl ether leading to a highly water soluble polymer 3 with $\mathrm{DS}_{\mathrm{HES}}$ (propargyl) $=0.55$.

Coupling of the CD azides $\mathbf{1 a}$ and $\mathbf{1 b}$ to the propargylated HES was performed by $\mathrm{Cu}^{+}$-catalyzed [ $\left.2+3\right]$ cycloaddition, the so-called click reaction, leading to the corresponding triazol<smiles>C#CCOC1CO1</smiles>

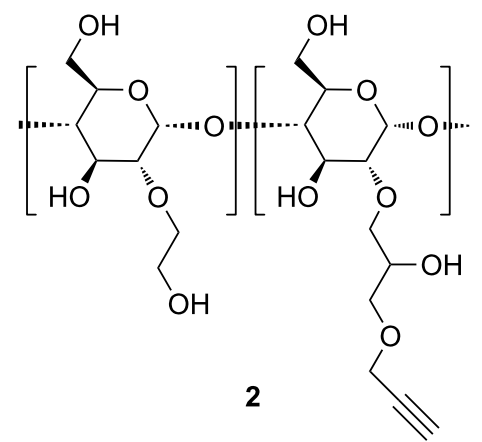




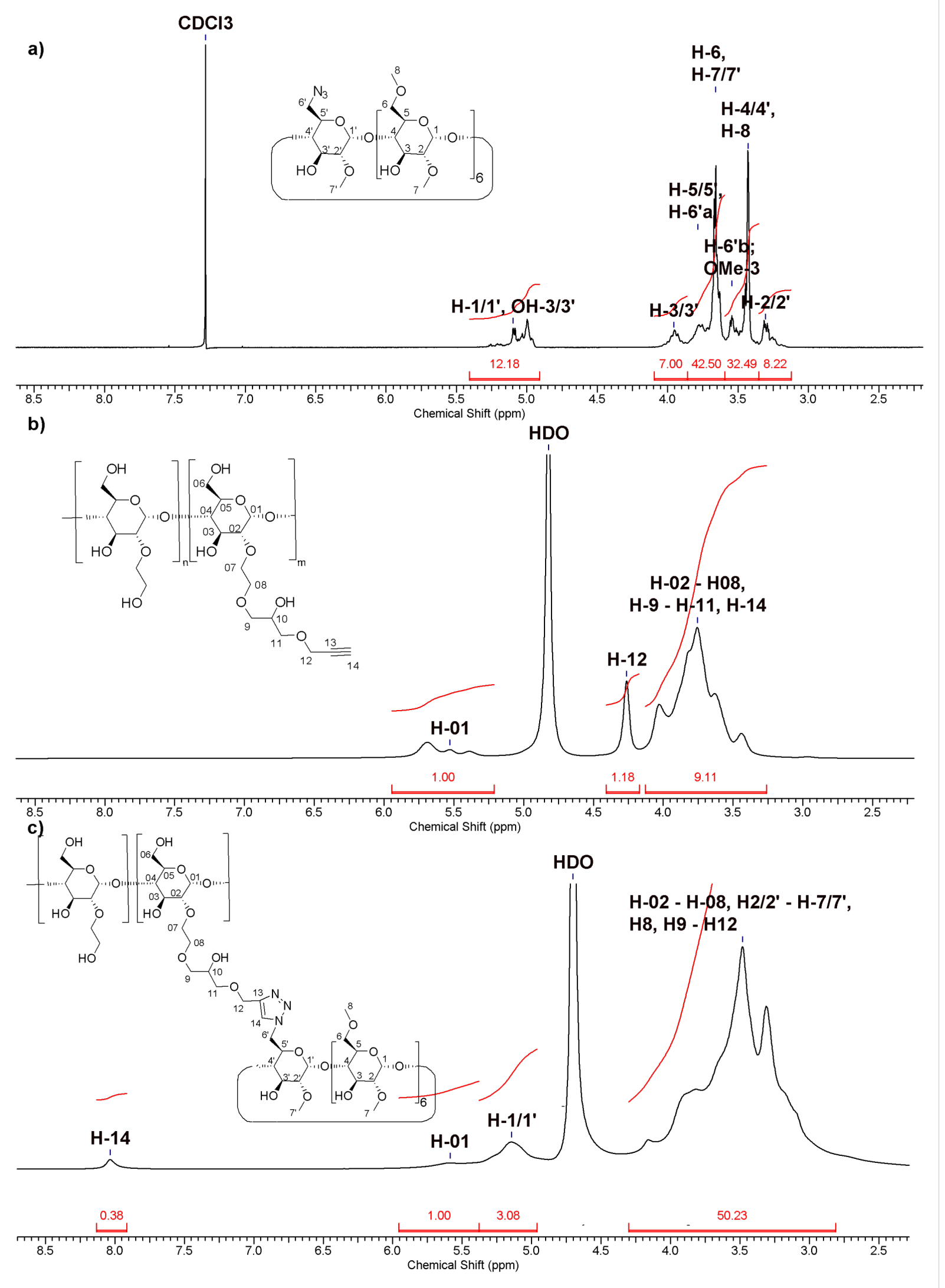

Figure 2: ${ }^{1} \mathrm{H}$ NMR spectra of a) 1a, b) 2, and c) $\mathbf{5 a}$. 
groups (Scheme 3). The standard protocol, introduced by Sharpless [31], using $\mathrm{CuSO}_{4}$ plus ascorbic acid as the catalyst already gave rise to high coupling yields. The resulting conjugates of HES and methylated CDs were isolated by ultrafiltration in nearly quantitative yields (Table 1). Nearly all propargyl groups at the HES detectable by the ${ }^{1} \mathrm{H}$ NMR signal $\mathrm{H}-12$ at $4.26 \mathrm{pm}$ were converted to triazole groups $\left({ }^{1} \mathrm{H}\right.$ NMR signal $\mathrm{H}-14$ at $8.03 \mathrm{ppm}$ ), shown in Figure 2c. The corresponding IR spectra (Figure 5s, Supporting Information File 2) revealed that the excess of azido-CD had been completely removed by the ultrafiltration step since the band of the azido group at $2102 \mathrm{~cm}^{-1}$ was not detectable anymore in the product. The degree of substitution of HES by $\mathrm{CD}, \mathrm{DS}_{\mathrm{HES}}(\mathrm{CD})$, was determined from the ratio of the ${ }^{1} \mathrm{H}$ NMR signals of $\mathrm{H}-14$ at $8.06 \mathrm{ppm}$ ( 0.38 protons) and of the anomeric proton $\mathrm{H}-01$ of starch at $5.66 \mathrm{ppm}$.

All of the methylated CD-HES conjugates, listed in Table 1, were clearly soluble in water at ambient conditions but most of them precipitated at elevated temperatures. This so-called lower critical solution temperature is typical for alkylated neutral polysaccharides and attributed to increasing hydrophobic interactions with increasing temperatures [47-49]. Only the CD-HES conjugate 6 did not show any precipitation below $100{ }^{\circ} \mathrm{C}$ which was attributed to the much higher hydrophilicity of the anionic carboxylate groups at the HES backbone compared to unmodified HES.

\section{Cytotoxicity assays}

The effect of the CD polymer 5a on the cell viability was assessed using the ATP-based CellTiter-Glo ${ }^{\circledR}$ assay [50] on the human colon tumor cell line Caco-2. A first series of tests was performed in the relevant concentration range, i.e., $10 \times$ lower and up to about $10 \times$ above the clinically relevant concentration, namely 0.25 till $25 \mathrm{mg} / \mathrm{mL}$ of the polymer $\mathbf{5 a}$ in the medium for $2 \mathrm{~h}$ and $24 \mathrm{~h}$ incubation times, respectively (Figure 3a,b). For comparison, the same viability test was carried out with DIMEB (Figure 3c,d).

According to DIN EN ISO 10993-5 [51], a more than 30\% deviation of measurement values of treated cells compared to the untreated control was defined as cytotoxic. After treatment

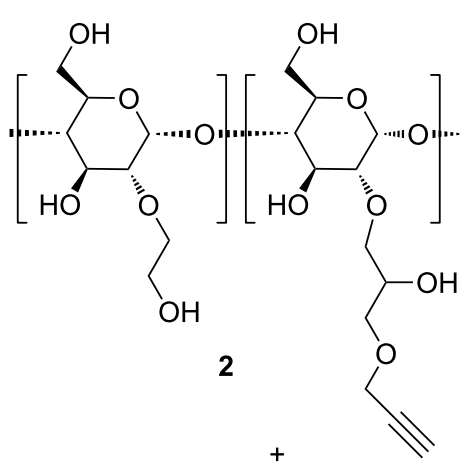

a)

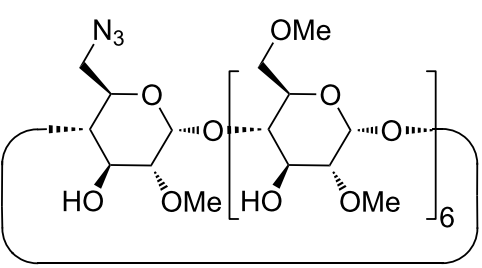

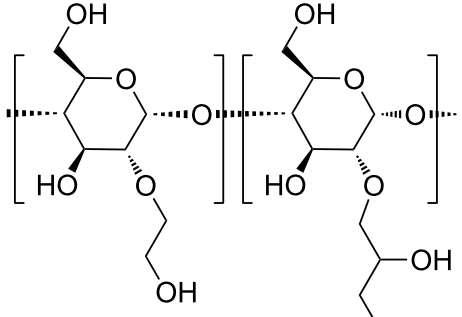

$5 a$

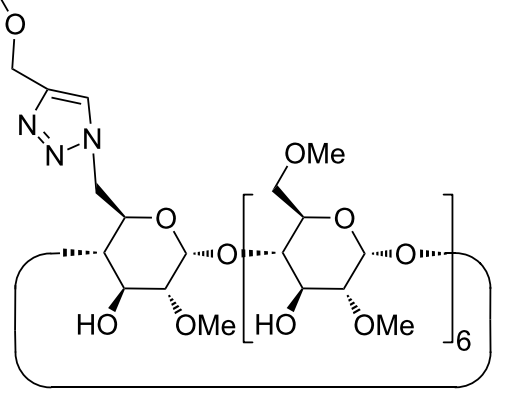

1a

Scheme 3: Synthesis of $5 \mathrm{a}$ by [2 +3$]$ cycloadditon, a) $\mathrm{CuSO}_{4}$, ascorbate, $50{ }^{\circ} \mathrm{C}, 48 \mathrm{~h}$.

Table 1: Compositions, yields, and LCST of methylated CD-HES conjugates synthesized by [2 +3$]$ cycloaddition.

\begin{tabular}{|c|c|c|c|c|c|c|}
\hline Name & $\mathrm{DS}_{\mathrm{CD}}(\mathrm{Me})$ & $\mathrm{DS}_{\mathrm{HES}}(\mathrm{CD})$ & $\mathrm{DS}_{\mathrm{HES}}(\mathrm{COONa})$ & Yield [\%] & $\mathrm{M}_{\mathrm{CD}}[\mathrm{Da}]$ & $\operatorname{LCST}\left[{ }^{\circ} \mathrm{C}\right]$ \\
\hline 4 & 0 & 0.1 & 0 & 70 & 3410 & no \\
\hline $5 a$ & 2.2 & 0.4 & 0 & 90 & 1985 & 52.5 \\
\hline $5 b$ & 2.3 & 0.35 & 0 & 94 & 2054 & 84.5 \\
\hline 6 & 2.2 & 0.45 & 0.27 & 95 & 1940 & no \\
\hline
\end{tabular}



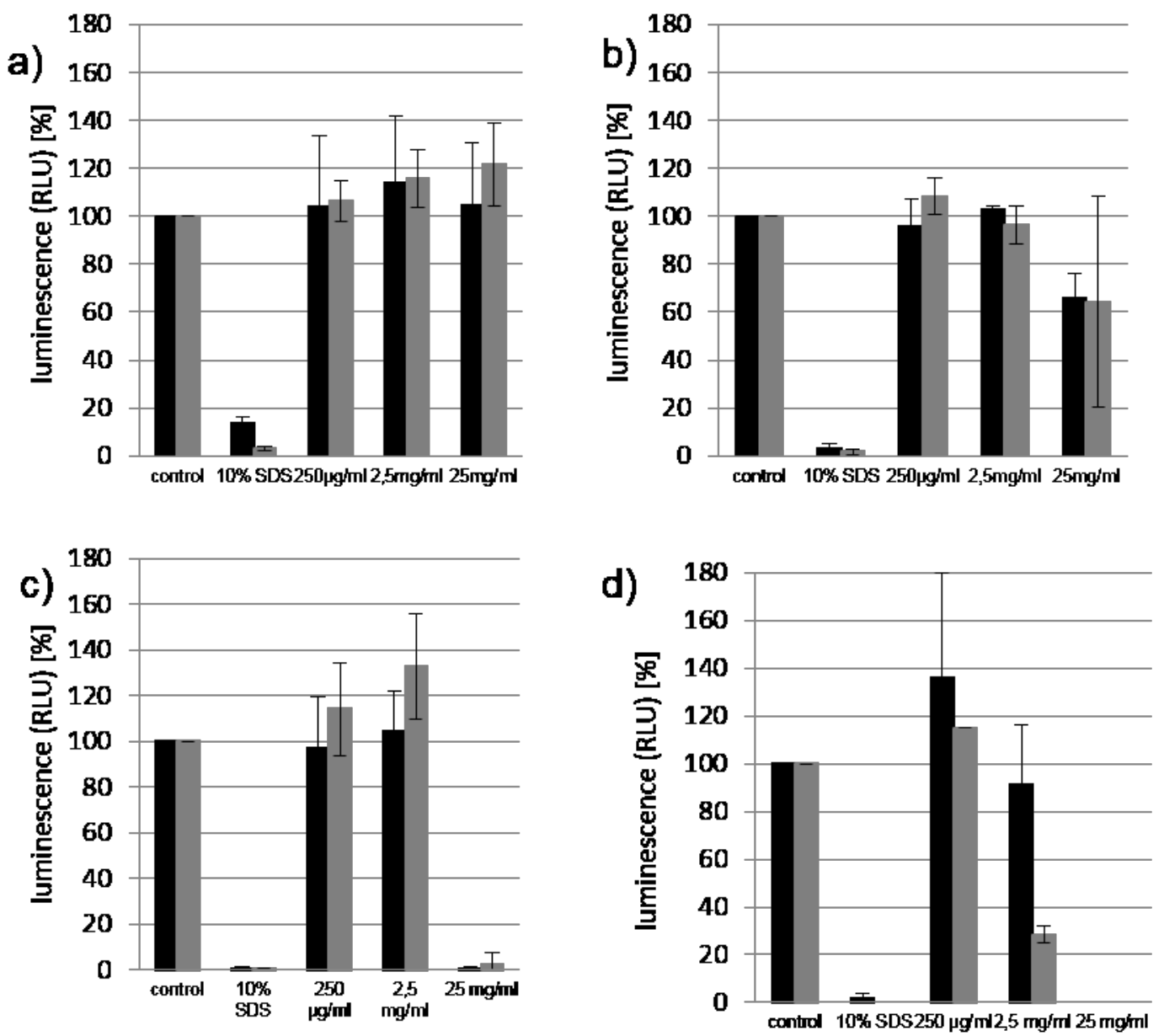

Figure 3: Viabilities of Caco-2 cells incubated with a) $5 a$ after $2 \mathrm{~h}$, b) 5 a after $24 \mathrm{~h}, \mathrm{c}$ ) DIMEB after $2 \mathrm{~h}$, d) DIMEB after $24 \mathrm{~h}$, in serum (black), in basal medium (grey).

of the Caco-2 cell line, not any cytotoxic effect could be detected for all of the tested concentrations of $\mathbf{5 a}$ after $2 \mathrm{~h}$ of incubation, while DIMEB was already highly toxic at $25 \mathrm{mg} / \mathrm{mL}$. After $24 \mathrm{~h}$ of incubation, 5a also showed a rather weak toxicity, while DIMEB was already highly toxic at the clinically relevant concentration (see Figure 3 ). The effect of the culture medium was negligible.

\section{Complexation of anaesthetic drugs by CD polymers}

The complexation of the anaesthetic drug sevoflurane (shown in Scheme 4) by the methylated CDs and CD polymers was quantified by measurement of the vapor pressure of the sevoflurane by gas chromatography as a function of the $\mathrm{CD}$ concentration as already described previously [14,52]. The respective occupancies of the hosts occupancies (the molar ratios of complexed guest vs. host) are listed in Table 2 . While native $\beta$-CD shows only a weak affinity to sevoflurane, the methylated CDs
RAMEB and especially DIMEB show satisfactory occupancies. Methylation increases the hydrophobicity of the CD cavity and therefore improves the compatibility with the hydrophobic guest sevoflurane. Surprisingly, the completely methylated $\beta$-CD TRIMEB had a much lower binding potential to sevoflurane than all other $C D$ derivatives. Low binding affinities of TRIMEB are also known towards other guest molecules, such as tert-butyl benzoate and adamantane-1-carboxylate, and had

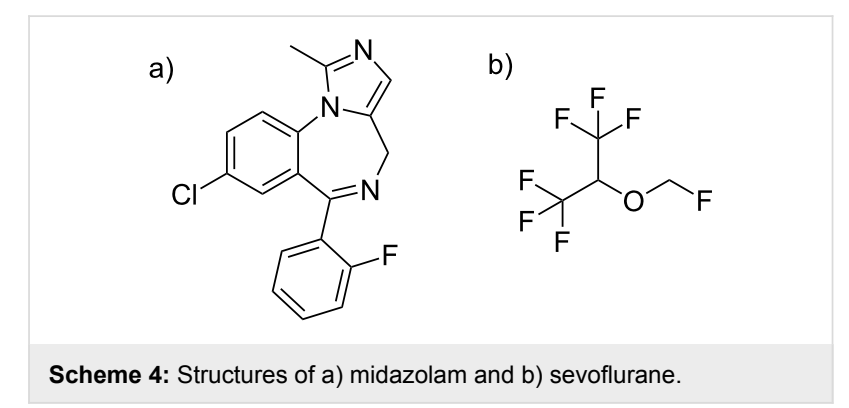


been rationalized by the lack of intramolecular hydrogen bonds which would otherwise rigidify the CD scaffold [16]. The occupancies of the HES polymers (see Table 2) also increased with increasing degree of methylation, $\mathrm{DS}_{\mathrm{CD}}\left(\mathrm{CH}_{3}\right)$ similar to the monomeric CDs. The anionic polymer 6 showed a somewhat smaller binding potential.

\begin{tabular}{|c|c|c|c|}
\hline Host & $\mathrm{DS}_{\mathrm{CD}}\left(\mathrm{CH}_{3}\right)$ & $\begin{array}{r}\text { Sevoflurane } \\
\text { [mol \%] }\end{array}$ & $\begin{array}{r}\text { Midazolam } \\
\text { [mol \%] }\end{array}$ \\
\hline$\beta-C D$ & 0 & 32 & 2 \\
\hline RAMEB & 1.8 & 47 & 6 \\
\hline DIMEB & 2.0 & 69 & 18 \\
\hline TRIMEB & 3.0 & 8 & $<1$ \\
\hline 4 & 0 & 34 & $<3$ \\
\hline $5 a$ & 2.2 & 67 & 24 \\
\hline $5 b$ & 2.3 & 67 & 26 \\
\hline 6 & 2.2 & 47 & 19 \\
\hline
\end{tabular}

The complexation of the anaesthetic drug midazolam (shown in Scheme 4) by the methylated CDs and CD polymers was quantified by the phase solubility method $[53,54]$. Solubility of midazolam was measured by UV spectroscopy as the function of the concentration of the $\mathrm{CD}$ derivative. The resulting occupancies are listed in Table 2. The value for native $\beta-\mathrm{CD}$ was quite low and in accordance with results previously obtained by ${ }^{1} \mathrm{H}$ NMR spectroscopy [55]. Again DIMEB showed the highest value. Occupancies of the polymers were in the same order of magnitude or even higher than for the respective CD monomers (Table 2).

\section{Conclusion}

The attachment of DIMEB to a polymer backbone by the clickreaction is a very efficient way to synthesise polymeric hosts with both low toxicity and excellent binding potential. The conjugate of DIMEB and HES 5a is regarded as a good candidate for oral or parenteral delivery of hydrophobic drugs.

\section{Experimental}

Complexation of sevoflurane. The vapor pressure of sevoflurane was determined by head space gas chromatography with a Shimadzu GC-17A GC equipped with a head space unit from Shimadzu, Japan. Vials of $5 \mathrm{~mL}$ volume were used, the ratio between gas $(V=3.2 \mathrm{~mL})$ and aqueous $(V=1.8 \mathrm{~mL})$ phase was $f=1.77$. Occupancies were calculated from the GC data as described previously [56].

Complexation of midazolam. An excess amount of midazolam was added to aqueous solutions containing various concentrations of $\mathrm{CD}$ polymers and stirred for $24 \mathrm{~h}$ at $25^{\circ} \mathrm{C}$.
After equilibration, aliquots of the suspension were filtered through a $0.20 \mu \mathrm{m}$ membrane cellulose filter, suitably diluted and analyzed using UV spectroscopy. The concentration of midazolam in each solution was determined by measuring its absorbance at $240 \mathrm{~nm}\left(\varepsilon=21,240 \mathrm{M}^{-1} \mathrm{~cm}^{-1}\right)$. The intrinsic absorption of each CD polymer was taken into account.

Cell viability was determined using CellTiter-Glo ${ }^{\circledR}$ assay (Promega, \#G7571) and Caco-2 colon carcinoma cells (DSMZ \#ACC-169; passage 9-17). Cells were cultured as described by the supplier, seeded with $5 \times 10^{3}$ cells per well in 96-well plates and tests carried out at about $80 \%$ cell confluency ( $\sim 3-4$ days). The assay results in cell lysis and generation of a luminescent signal proportional to the amount of ATP present, which is directly proportional to the number of cells in culture. The luminescence signal was measured in a plate reader (infinite M200, TECAN, Männedorf, Swizerland). 5a and DIMEB were each solved in standard basal medium (MEM) or human serum and cells were treated for $2 \mathrm{~h}$ and $24 \mathrm{~h}$ with the above-mentioned concentrations. For viability assessment, the test substances were removed by washing with PBS buffer $\left(\right.$ Sigma $\left.^{\circledR}\right)$, the cells in each well were overlaid with $100 \mu \mathrm{L}$ of basal medium and $100 \mu \mathrm{L}$ of CellTiter-Glo ${ }^{\circledR}$ reagent and luminescence was measured after 2 min of shaking and $10 \mathrm{~min}$ incubation at room temperature in the TECAN plate reader. All results presented are based on at least three independent biological tests. Statistical significance was determined by analysis of variance and $p<0.05$.

Materials: Hydroxyethyl starch (HES) with an average molar mass $\left(M_{\mathrm{W}}\right)$ of $130 \mathrm{kDa}$ and a molar substitution of 0.4 was kindly provided by Fresenius Kabi, Friedberg, Germany (batch no: 17120211). $\beta$-CD was obtained from Wacker Chemie $\mathrm{GmbH}$, München, Germany. HES and CD were used after drying overnight at $70{ }^{\circ} \mathrm{C}$ under reduced pressure. All other reagents and solvents were purchased from commercial suppliers and used as received. Mono-6-deoxy-6-azido- $\beta$-CD was synthesized according to a literature protocol [57]. All complexation studies were performed in saline HEPES-buffer solution ( $\mathrm{pH} 7.4$ ) with a $\mathrm{NaCl}$ concentration of $0.9 \mathrm{wt} \%$.

Mono-6-deoxy-6-azido-heptakis(2,6-di- $O$-methyl)- $\beta$ cyclodextrin (1a): $3.0 \mathrm{~g}$ (2.59 mmol) mono-(6-deoxy-6-azido)$\beta$-CD was dissolved in $150 \mathrm{~mL}$ DMF/DMSO 1:1 (v/v) under $\mathrm{N}_{2}$ and a mixture of $26 \mathrm{~g}$ (168 mmol) $\mathrm{BaO}$ and $26 \mathrm{~g} \mathrm{Ba}(\mathrm{OH})_{2}$ $(153 \mathrm{mmol})$ was added in small portions within 10 min under stirring. The mixture was cooled to $0{ }^{\circ} \mathrm{C}$ and $30 \mathrm{~mL}(0.32 \mathrm{~mol})$ dimethyl sulfate was added over a period of $1 \mathrm{~h}$ under intensive stirring keeping the internal temperature below $5{ }^{\circ} \mathrm{C}$. Stirring was continued for $4 \mathrm{~d}$ at rt. Then the mixture was warmed up to $85^{\circ} \mathrm{C}$ for $30 \mathrm{~min}$. After cooling to $\mathrm{rt}$, excess dimethyl sulfate 
was decomposed by addition of $50 \mathrm{~mL}$ of $25 \mathrm{wt} \%$ aqueous ammonia. The mixture was stirred for $16 \mathrm{~h}$ and neutralized by addition of conc. $\mathrm{HCl}$. Then $180 \mathrm{~mL}$ chloroform was added, filtered and the precipitate was washed with further $80 \mathrm{~mL}$ chloroform. The filtrate was concentrated to dryness in vacuum, dissolved in water, purified by nanofiltration with water against a polyethersulfone membrane (cut-off: $1 \mathrm{kDa}$ ) and lyophilized.

Yield: $2.5 \mathrm{~g}$ (1.86 mmol, 72\%); DS: $2.2 ;{ }^{1} \mathrm{H}$ NMR (400 MHz, $\left.\mathrm{CDCl}_{3}\right) \delta$ 5.25-4.94 (m, 12H, H-1/1', OH-3/3'), 3.94-3.92 (m, 7H, H-3/3'), 3.75-3.40 (m, 74H, H-4/4', H-5/5', H-6/6'a/6’b, $\left.\mathrm{H}-7 / 7^{\circ}, \mathrm{H}-8, \mathrm{H}-9\right), 3.29-3.21$ (m, 7H, H-2/2 $\left.{ }^{\circ}\right) ;{ }^{13} \mathrm{C}$ NMR (100 $\left.\mathrm{MHz}, \mathrm{CDCl}_{3}\right) \delta 101.3(\mathrm{C}-1), 83.5(\mathrm{C}-4), 82.0(\mathrm{C}-2), 73.2(\mathrm{C}-3)$, 70.8 (C-6a/b), 70.3 (C-5), 61.7 - 58.2 (C-7, C-8, C-9), 51.8 (C-6'a/b); $\mathrm{MS}(\mathrm{m} / \mathrm{z}):\left[\mathrm{M}+\mathrm{Na}^{+}\right]$1364.63, $\mathrm{C}_{55} \mathrm{H}_{95} \mathrm{~N}_{3} \mathrm{O}_{34},(\mathrm{~m} / \mathrm{z})$ : $\left[\mathrm{M}+\mathrm{Na}^{+}+\mathrm{CH}_{3}\right]$ 1378.02, $\mathrm{C}_{56} \mathrm{H}_{97} \mathrm{~N}_{3} \mathrm{O}_{34},(m / z):\left[\mathrm{M}+\mathrm{Na}^{+}+\right.$ $\left.2 \mathrm{CH}_{3}\right]$ 1392.64, $\mathrm{C}_{57} \mathrm{H}_{99} \mathrm{~N}_{3} \mathrm{O}_{34}$, most intense peak $(\mathrm{m} / z)$ : $[\mathrm{M}+$ $\left.\mathrm{Na}^{+}+3 \mathrm{CH}_{3}\right]$ 1406.29, $\mathrm{C}_{58} \mathrm{H}_{101} \mathrm{~N}_{3} \mathrm{O}_{34},(m / z):\left[\mathrm{M}+\mathrm{Na}^{+}+\right.$ $\left.4 \mathrm{CH}_{3}\right]$ 1420.20, $\mathrm{C}_{59} \mathrm{H}_{103} \mathrm{~N}_{3} \mathrm{O}_{34}$; IR $\tilde{v}\left(\mathrm{~cm}^{-1}\right): 3412(\mathrm{OH}), 2930$ $(\mathrm{CH}), 2102\left(\mathrm{~N}_{3}\right), 1453(\mathrm{CH}), 1361(\mathrm{OH})$.

(3-Propargyloxy-2-hydroxypropyl)-hydroxyethyl starch (2): $3.412 \mathrm{~g}$ (18.98 mmol) HES was dissolved in $40 \mathrm{~mL} 0.1 \mathrm{M}$ $\mathrm{NaOH}$ and $1.8 \mathrm{~mL}(16.70 \mathrm{mmol})$ glycidyl propargyl ether were added. The temperature was increased to $35^{\circ} \mathrm{C}$ and the solution was stirred. After $24 \mathrm{~h}$ further $1.8 \mathrm{~mL}(16.70 \mathrm{mmol})$ glycidyl propargyl ether were added and stirred for another $16 \mathrm{~h}$. The product was precipitated in $500 \mathrm{~mL}$ 2-propanol, filtered and washed with $200 \mathrm{~mL}$ 2-propanol. The product was purified by ultrafiltration with water against a polyethersulfone membrane (cut-off: $5 \mathrm{kDa}$ ) and freeze-dried.

Yield: $3.61 \mathrm{~g}$ (14.97 mmol, 79\%); DS: 0.65; ${ }^{1} \mathrm{H}$ NMR (400 $\left.\mathrm{MHz}, \mathrm{DMSO}-d_{6} / \mathrm{D}_{2} \mathrm{O}\right) \delta 5.68-5.38\left(\mathrm{~m}, 1 \mathrm{H}, \mathrm{H}-01 / 01^{\circ}\right), 4.27$ (s, $1.30 \mathrm{H}, \mathrm{H}-12^{\circ}$ ), 4.03-3.45 (m, 10H, H-02/02‘, H-03/03', H-04/ 04', H-05/05‘, H-06/06‘, H-07/07`, H-08/08,H-9‘, H-10‘, $\left.\mathrm{H}-11^{`}, \mathrm{H}-14^{\circ}\right)$; IR $\tilde{v}\left(\mathrm{~cm}^{-1}\right): 3400.25(\mathrm{OH}), 2925.80(\mathrm{CH})$, $2113.83(-\mathrm{C} \equiv \mathrm{C}), 1456.15(\mathrm{CH}), 1365.50(\mathrm{OH})$.

Conjugate of DIMEB and HES 5a: Under an atmosphere of $\mathrm{N}_{2} 1.6 \mathrm{~g}(1.19 \mathrm{mmol}) \mathbf{1 a}$ was dissolved in $40 \mathrm{~mL}$ of degassed $\mathrm{DMSO} / \mathrm{H}_{2} \mathrm{O} 1: 1(\mathrm{v} / \mathrm{v})$ and $600 \mathrm{mg}(2.4 \mathrm{mmol}) 2$ and $334 \mu \mathrm{L}$ $(119 \mu \mathrm{mol})$ of a solution of sodium ascorbate in water $(70 \mathrm{mg} / \mathrm{mL})$ were added. After reaching $50{ }^{\circ} \mathrm{C}, 211 \mu \mathrm{L}$ $(59 \mu \mathrm{mol})$ of a solution of $\mathrm{CuSO}_{4} \cdot 5 \mathrm{H}_{2} \mathrm{O}$ in water $(70 \mathrm{mg} / \mathrm{mL})$ was added. The solution was stirred for $48 \mathrm{~h}$ and purified by ultrafiltration with water against a polyethersulfone membrane (cut-off: $5 \mathrm{kDa}$ ) and freeze-dried.

Yield: $1.67 \mathrm{~g}$ (2.15 mmol, 90\%); DS: 0.4; ${ }^{1} \mathrm{H}$ NMR: (400 MHz, $\left.\mathrm{D}_{2} \mathrm{O}\right) \delta 8.03\left(\mathrm{~s}, 0.4 \mathrm{H}, \mathrm{H}-14^{\circ}\right), 5.58\left(\mathrm{~m}, 1 \mathrm{H}, \mathrm{H}-01 / 01^{\circ}\right), 5.14(\mathrm{~m}$,
2.8H, H-1/1 '), 3.86-3.07 (m, 45H, H-02/02`-H-08/08`, H2/ $\left.2^{`}-\mathrm{H}-7 / 7^{`}, \mathrm{H} 8, \mathrm{H}^{`}-\mathrm{H} 12^{`}\right)$; IR $\tilde{v}\left(\mathrm{~cm}^{-1}\right): 3400.25(\mathrm{OH})$, $2925.80(\mathrm{CH}), 1456.15(\mathrm{CH}), 1365.50(\mathrm{OH})$.

\section{Supporting Information}

\section{Supporting Information File 1}

General methods and experimental procedures for compounds $\mathbf{1 b}, \mathbf{3}, \mathbf{4}, \mathbf{5 b}$ and for the oxidation of HES.

[http://www.beilstein-journals.org/bjoc/content/ supplementary/1860-5397-10-325-S1.pdf]

\section{Supporting Information File 2}

NMR spectra of HES, 1a, $\mathbf{1 b}, \mathbf{6}$, and IR spectra of HES, $\mathbf{2}$,

5a.

[http://www.beilstein-journals.org/bjoc/content/

supplementary/1860-5397-10-325-S2.pdf]

\section{Acknowledgements}

This work was funded by the Federal Ministry of Research and Technology (BMBF), Project No. 13N11804. Thanks to Devid Hero and Jessica Hilschmann for their synthetic work, Annegret Engelke and Blandine Boßmann for UV spectroscopy and GC headspace measurements.

\section{References}

1. Szejtli, J. Pure Appl. Chem. 2004, 76, 1825-1845. doi:10.1351/pac200476101825

2. Rekharsky, M. V.; Inoue, Y. Chem. Rev. 1998, 98, 1875-1918. doi:10.1021/cr970015o

3. Wang, W.; Kaifer, A. E. Cucurbituril and Cyclodextrin Complexes of Dendrimers. In Inclusion Polymers; Wenz, G., Ed.; Springer-Verlag: Berlin, 2009; Vol. 222, pp 1-54. doi:10.1007/12_2008_1

4. Irie, T.; Uekama, K. J. Pharm. Sci. 1997, 86, 147-162. doi:10.1021/js960213f

5. Kiss, T.; Fenyvesi, F.; Bácskay, I.; Váradi, J.; Fenyvesi, É.; Iványi, R.; Szente, L.; Tósaki, Á.; Vecsernyés, M. Eur. J. Pharm. Sci. 2010, 40, 376-380. doi:10.1016/j.ejps.2010.04.014

6. Frank, D. W.; Gray, J. E.; Weaver, R. N. Am. J. Pathol. 1976, 83, 367-382.

7. Frijlink, H. W.; Eissens, A. C.; Hefting, N. R.; Poelstra, K.; Lerk, C. F.; Meijer, D. K. F. Pharm. Res. 1991, 8, 9-16. doi:10.1023/A:1015861719134

8. Kimura, E.; Bersani-Amado, C. A.; Sudo, L. S.; Santos, S. R. J.; Oga, S. Gen. Pharmacol. 1997, 28, 695-698. doi:10.1016/S0306-3623(96)00362-X

9. Brewster, M. E.; Loftsson, T. Adv. Drug Delivery Rev. 2007, 59, 645-666. doi:10.1016/j.addr.2007.05.012

10. Bilensoy, E., Ed. Cyclodextrins in pharmaceutics, cosmetics, and biomedicine; John Wiley \& Sons: Hoboken, NJ, 2011; pp 1-395. doi:10.1002/9780470926819.ins

11. Loftsson, T.; Brewster, M. E. J. Pharm. Pharmacol. 2010, 62, 1607-1621. doi:10.1111/j.2042-7158.2010.01030.x 
12. Leroy-Lechat, F.; Wouessidjewe, D.; Andreux, J.-P.; Puisieux, F.; Duchêne, D. Int. J. Pharm. 1994, 101, 97-103. doi:10.1016/0378-5173(94)90080-9

13. Zia, V.; Rajewski, R. A.; Stella, V. J. Pharm. Res. 2001, 18, 667-673. doi:10.1023/A:1011041628797

14. Fourmentin, S.; Ciobanu, A.; Landy, D.; Wenz, G. Beilstein J. Org. Chem. 2013, 9, 1185-1191. doi:10.3762/bjoc.9.133

15. Szejtli, J.; Liptak, A.; Jodal, I.; Fügedi, P.; Nanasi, P.; Neszmelyi, A. Starch/Staerke 1980, 32, 162-164.

16. Wenz, G. Beilstein J. Org. Chem. 2012, 8, 1890-1895 doi:10.3762/bjoc.8.218

17. Szejtli, J. J. Inclusion Phenom. Macrocyclic Chem. 1983, 1, 135-150. doi:10.1007/BF00656816

18. Carrier, R. L.; Miller, L. A.; Ahmed, I. J. Controlled Release 2007, 123, 78-99. doi:10.1016/j.jconrel.2007.07.018

19. Challa, R.; Ahuja, A.; Ali, J.; Khar, R. K. AAPS PharmSciTech 2005, 6, R329-E357. doi:10.1208/pt060243

20. Cheng, J.; Khin, K. T.; Jensen, G. S.; Liu, A.; Davis, M. E. Bioconjugate Chem. 2003, 14, 1007-1017. doi:10.1021/bc0340924

21. Weickenmeier, M.; Wenz, G. Macromol. Rapid Commun. 1996, 17, 731-736. doi:10.1002/marc.1996.030171008

22. Ramírez, H. L.; Valdivia, A.; Cao, R.; Torres-Labandeira, J. J.; Fragoso, A.; Villalonga, R. Bioorg. Med. Chem. Lett. 2006, 16, 1499-1501. doi:10.1016/j.bmcl.2005.12.049

23. Ramirez, H. L.; Valdivia, A.; Cao, R.; Fragoso, A.; Torres Labandeira, J. J.; Baños, M.; Villalonga, R. Polym. Bull. 2007, 59, 597-605. doi:10.1007/s00289-007-0803-8

24. Gomez, C. G.; Chambat, G.; Heyraud, A.; Villar, M.; Auzély-Velty, R. Polymer 2006, 47, 8509-8516. doi:10.1016/j.polymer.2006.10.011

25. Charlot, A.; Heyraud, A.; Guenot, P.; Rinaudo, M.; Auzély-Velty, R. Biomacromolecules 2006, 7, 907-913. doi:10.1021/bm0507094

26. Aoki, N.; Nishikawa, M.; Hattori, K. Carbohydr. Polym. 2003, 52, 219-223. doi:10.1016/S0144-8617(02)00308-9

27. Prabaharan, M.; Mano, J. F. Macromol. Biosci. 2005, 5, 965-973. doi:10.1002/mabi.200500087

28. Nielsen, T. T.; Wintgens, V.; Amiel, C.; Wimmer, R.; Larsen, K. L. Biomacromolecules 2010, 11, 1710-1715. doi:10.1021/bm9013233

29. Yuan, Z.; Ye, Y.; Gao, F.; Yuan, H.; Lan, M.; Lou, K.; Wang, W. Int. J. Pharm. 2013, 446, 191-198. doi:10.1016/j.ijpharm.2013.02.024

30. Huisgen, R.; Szeimies, G.; Möbius, L. Chem. Ber. 1967, 100, 2494-2507. doi:10.1002/cber.19671000806

31. Rostovtsev, V. V.; Green, L. G.; Fokin, V. V.; Sharpless, K. B. Angew. Chem., Int. Ed. 2002, 41, 2596-2599. doi:10.1002/1521-3773(20020715)41:14<2596::AID-ANIE2596>3.0.CO ;2-4

32. Wang, Q.; Chan, T. R.; Hilgraf, R.; Fokin, V. V.; Sharpless, K. B.; Finn, M. G. J. Am. Chem. Soc. 2003, 125, 3192-3193. doi:10.1021/ja021381e

33. Treib, J.; Baron, J.-F.; Grauer, M. T.; Strauss, R. G. Intensive Care Med. 1999, 25, 258-268. doi:10.1007/s001340050833

34. Schortgen, F.; Deye, N.; Brochard, L. Intensive Care Med. 2004, 30 , 2222-2229. doi:10.1007/s00134-004-2415-1

35. Boldt, J. Anesth. Analg. 2009, 108, 1574-1582. doi:10.1213/ane.0b013e31819e9e6c

36. Delgado-Herrera, L.; Ostroff, R. D.; Rogers, S. A. CNS Drug Rev. 2001, 7, 48-120. doi:10.1111/j.1527-3458.2001.tb00190.x

37. Gudmundsdottir, H.; Sigurjonsdottir, J. F.; Masson, M.; Fjalldal, O.; Stefansson, E.; Loftsson, T. Pharmazie 2001, 56, 963-966.
38. Marcon, F.; Mathiron, D.; Pilard, S.; Lemaire-Hurtel, A.-S.; Dubaele, J.-M.; Djedaini-Pilard, F. Int. J. Pharm. 2009, 379, 244-250. doi:10.1016/j.jpharm.2009.05.029

39. Hocquelet, C.; Blu, J.; Jankowski, C. K.; Arseneau, S.; Buisson, D.; Mauclaire, L. Tetrahedron 2006, 62, 11963-11971. doi:10.1016/j.tet.2006.09.089

40. Casu, B.; Reggiani, M.; Gallo, G. G.; Vigevani, A. Tetrahedron 1968, 24, 803-821. doi:10.1016/0040-4020(68)88030-5

41. Wimmer, T. Preparation of alkylated cyclodextrin derivatives, methylated cyclodextrin derivatives and their use. U.S. Patent 5710268, April 5, 1994.

42. Gelb, R. I.; Schwartz, L. M.; Bradshaw, J. J.; Laufer, D. A. Bioorg. Chem. 1980, 9, 299-304. doi:10.1016/0045-2068(80)90039-5

43. Gelb, R. I.; Schwartz, L. M.; Laufer, D. A. Bioorg. Chem. 1982, 11, 274-280. doi:10.1016/0045-2068(82)90003-7

44. Augsten, C. Asymmetrische Fluß Feld-Fluß Fraktionierung in Verbindung mit Mehrwinkellichtstreudetektion - Eine neue bedeutende Methode der Pharmazeutischen Analytik zur Charakterisierung von Makromolekülen und Nanopartikeln. Ph.D. Thesis, Martin-Luther-Universität, Halle-Wittenberg, Germany, 2008.

45. Thiele, C.; Auerbach, D.; Jung, G.; Qiong, L.; Schneider, M.; Wenz, G. Polym. Chem. 2011, 2, 209-215. doi:10.1039/c0py00241k

46. Bragd, P. L.; Besemer, A. C.; van Bekkum, H. Carbohydr. Res. 2000, 328, 355-363. doi:10.1016/S0008-6215(00)00109-9

47. Kern, H.; Choi, S.; Wenz, G.; Heinrich, J.; Ehrhardt, L.; Mischnick, P.; Garidel, P.; Blume, A. Carbohydr. Res. 2000, 326, 67-79. doi:10.1016/S0008-6215(00)00024-0

48. Yan, J.; Li, W.; Zhang, X.; Liu, K.; Wu, P.; Zhang, A. J. Mater. Chem. 2012, 22, 17424-17428. doi:10.1039/c2jm33328g

49. Ju, B.; Zhang, C.; Zhang, S. Carbohydr. Polym. 2014, 108, 307-312. doi:10.1016/j.carbpol.2014.02.057

50. Hannah, R.; Beck, M.; Moravec, R.; Riss, T. Promega Cell Notes 2001 , 2, 11-13.

51. ISO 10993-5:2009(en) Biological evaluation of medical devices - Part 5: Tests for in vitro cytotoxicity. https://www.iso.org/obp/ui/\#iso:std:iso:10993:-5:ed-3:v1:en.

52. Lantz, A. W.; Wetterer, S. M.; Armstrong, D. W. Anal. Bioanal. Chem. 2005, 383, 160-166. doi:10.1007/s00216-005-0030-9

53. Higuchi, T.; Connors, K. A. Adv. Anal. Chem. Instrum. 1965, 4, 117-212.

54. Connors, K. A. Chem. Rev. 1997, 97, 1325-1358. doi:10.1021/cr960371r

55. Ali, S. M.; Upadhyay, S. K. Magn. Reson. Chem. 2008, 46, 676-679. doi:10.1002/mrc.2231

56. Becker, L. F.; Schwarz, D. H.; Wenz, G. Beilstein J. Org. Chem. 2014, 10, 2920-2927. doi:10.3762/bjoc.10.310

57. Tang, W.; Ng, S.-C. Nat. Protoc. 2008, 3, 691-697. doi:10.1038/nprot.2008.37 


\section{License and Terms}

This is an Open Access article under the terms of the Creative Commons Attribution License

(http://creativecommons.org/licenses/by/2.0), which permits unrestricted use, distribution, and reproduction in any medium, provided the original work is properly cited.

The license is subject to the Beilstein Journal of Organic Chemistry terms and conditions:

(http://www.beilstein-journals.org/bjoc)

The definitive version of this article is the electronic one which can be found at:

doi:10.3762/bjoc. 10.325 